

\title{
John Dawson and Masao Mukoyama. Global Strategies in Retailing: Asian and European Experiences \\ Latchezar Hristov
}

\section{To cite this version:}

Latchezar Hristov. John Dawson and Masao Mukoyama. Global Strategies in Retailing: Asian and European Experiences. Journal of Marketing Channels, 2015, 22 (3), pp.239-241. 10.1080/1046669X.2015.1071597 . hal-01217306

\section{HAL Id: hal-01217306 \\ https://hal-audencia.archives-ouvertes.fr/hal-01217306}

Submitted on 19 Oct 2015

HAL is a multi-disciplinary open access archive for the deposit and dissemination of scientific research documents, whether they are published or not. The documents may come from teaching and research institutions in France or abroad, or from public or private research centers.
L'archive ouverte pluridisciplinaire HAL, est destinée au dépôt et à la diffusion de documents scientifiques de niveau recherche, publiés ou non, émanant des établissements d'enseignement et de recherche français ou étrangers, des laboratoires publics ou privés. 


\section{BOOK REVIEW}

\section{Global Strategies in Retailing: Asian and European Experiences}

London, UK: Routledge (2014) pp. 252

Book Edited by John Dawson and Masao Mukoyama

This book, comprising a collection of articles edited by John Dawson and Masao Mukoyama, will appeal to a wide audience of both academics and practitioners. With contributions from international scholars, the volume offers a comprehensive overview of history, contemporary practices, and future directions of retail internationalization with particular focus on Asian and European companies. Within its eleven chapters it blends conceptual, empirical, and case studybased papers linked through the application of the global portfolio strategy paradigm. The reader is steered from discussion of the broader industry-wide context and historical evolution of international retailing to more textured analyses of present day retailer strategies.

In their introduction the authors explore the strengths and limitations of current theories pertaining to international retailing in accounting for the rapidly evolving multiformat and multicontinental contemporary practices of retailers. As intermediaries, retailers represent an eclectic group of businesses with an output comprising a mixture of physical goods, distribution, and consumer services. Once seen mostly as local resellers of manufacturers' products, today modern international retailers have become global megabrands in their own right with strong impacts upon patterns of consumption, supplier networks, and urban planning and development.

The first three chapters examine the evolution of international retailing from earlier entrepreneurial, cross-border pursuits of growth to present day, more organized global portfolio strategies. Here the authors explain the rapid international growth of retailers as a result of global 
political and economic changes resulting in ongoing trade liberalization. This, coupled with applications of new retail technologies, management learning, and sustained investment in international growth, has propelled once local retailers fully onto the international stage. The authors draw on structuration theory in highlighting international retailers' increasing endeavors to immerse themselves in the economic, sociocultural, and political environments in which they operate. Greater integration of internal and external resources (i.e., agency) with internal and external environments (i.e., structure) has facilitated the adoption of global portfolio strategies aimed at optimizing and managing effectively complex portfolios of retail brands, formats, and formulas.

In chapter 2 the authors distinguish between the terms retail format and formula. Whilst retail formats are business models described as a generalized set of relationships defined by particular cost structures, retail formulae identify the very places of transaction where retailerconsumer interactions take place. Further on they introduce the concept of the global portfolio strategy as a new way of leveraging synergies and co-ordination among multiple retail business units across multiple continents. The authors visualize this concept with a retail "GPS map": an analytical tool for understanding strategic shifts of international retailers over time. The next seven chapters (4-10) are case study-based, providing exemplars of the international strategies of Asian and European retailers. These include IKEA, Lotte Shopping, MUJI, Nitori, President Chain Store Corporation, and the Delhaize and Metro Groups.

The first case (chapter 4) is that of Nitori. From being a small retailer in Hokkaido Nitori has grown to become the leading Japanese furniture retailer with a global sourcing network and international stores in Taiwan. Their uninterrupted growth has been attributed to a dual manufacturing-retailing model, combining an international production network with an 
expanding range of store formats and formulas for affordable, design-led furniture and home fashion accessories.

Chapter 5 is another example of a global portfolio strategy based on business diversification. President Chain Store Corporation is a vertically integrated Taiwanese food conglomerate with a portfolio of franchises including 7-Eleven. Synchronizing vertical and horizontal diversification has allowed the company to grow internationally initially through a network of subsidiaries, joint ventures, and partnerships into the neighboring markets of China, Vietnam, and Indonesia and subsequently further afield in the United States (U.S.) and Russia.

Similarly, Lotte Shopping (discussed in chapter 6), with headquarters in Seoul, has grown by building an extensive portfolio of formats including department stores, hypermarkets, supermarkets, convenience stores, home shopping, and internet retailing. They have been successful in achieving vertical and horizontal synergies, whilst adapting their market entry strategies to the fast-growing retail markets of Asia.

In some contrast to the previous examples, chapter 7 examines IKEA's standardized model of growth on four continents based on its three elements: a single "big box" retail format, a catalogue, and an almost uniform range of 10,000 items comprising "flat-pack" furniture and housewares. The consistency of the IKEA concept across markets has been further reinforced by an in-house design department, an integrated global supply chain, and an international network of dedicated suppliers. Yet the concept provides for some market adaptations within the product range, advertising, store planning, and customer service areas.

MUJI (in chapter 8) is another case of a largely standardized multicontinent strategy pursued by a single-format retailer. Although part of a larger group, MUJI remains a niche retailer of private label products. Its distinct concept is centered on selling high-quality, non- 
branded clothing and household products across Japan and the world. After an initial expansion in neighboring Singapore, Thailand, and Hong Kong, the company has grown further afield in the U.S. and Europe. Whilst its retail concept remains standardized, MUJI has been successful in codeveloping with local designers products rooted in the cultures of its international markets.

Yet another configuration of the GPS map is presented in chapter 9 through the case of the Delhaize Group. It eloquently charts out the international growth of the largest Belgian retailer. Belgium is a relatively small retail market that, coupled with retail legislation at the time restricting European growth of large grocery stores, has brought about change in Delhaize's growth strategy. The retailer withdrew altogether from European hypermarkets to concentrate on its growth in the U.S. where through acquisitions and investments Delhaize became an established, multibrand retailer. This strategy has been so successful that at present its chains in the U.S. account for over $60 \%$ of the group's overall revenues. Further expansion through acquisition in Southeast Europe and Asia paints a picture of dynamic international growth through multiple modes of market entry.

The case of the German Metro Group, in chapter 10, presents a multiformat, multicontinent portfolio strategy on a global scale. In this case Metro is more standardized than Delhaize, yet equally diversified. Metro is among the largest retailers with operations in 32 countries on three continents. Their global portfolio strategy has emerged through consecutive phases of international growth over time. The company defines standardized formats, which are then tested, rolled out internationally, and subsequently adapted locally. This case study pinpoints the variable international success of Metro's different retail formats with some, such as Metro Cash \& Carry, proving to be more resilient and better adapted to economic fluctuations across different markets. 
The concluding chapter 11 is a summary of key findings and reflections on the future directions of retailer internationalization. The authors point out that internationalization in retailing is evolving through various phases and that the global portfolio strategy is the latest but certainly not final one. Modern retailers are complex and geographically dispersed organizations in need of focus and flexibility. Many adopt portfolio strategies to develop synergies and maintain growth through scale-related cost economies.

Yet, such an approach is not without challenges. Some of these include retailers' managerial and technological capacity to devise workable implementation mechanisms and structures across multiple international formats and formulae. The authors emphasize the need for exploring these challenges and opportunities through broadening the theoretical bases of the research area and drawing on sociology, social science, and organization theory (most notably the theories of structuration, embeddedness, or by means of the resource-based perspective on internationalization) to do so.

This volume is a welcome addition to a relatively short list of books dedicated to international retailing. Although for some time now the industry has been a major contributor to global gross domestic product as an innovator of products, services, and technologies, somehow retailing still receives less attention than it merits in the broader management literature. This volume presents research of a high standard, organized in a clear and logical way. The balance between conceptual and empirical papers with reference to Asian and European retailers has achieved important insights and depth that scholars and practitioners on the subject will find very useful and stimulating. Perhaps one area which could have been examined a little further would be innovation and globalization of nonstore retailing. We have recently seen rapid proliferation of e-commerce and multichannel-channel modes of retailing both in Asia and Europe. These 
have provided retailers with the capacity to grow abroad beyond simple exponential investment in store-based retailing.

As a whole this book works on different levels. Alongside its practical benefits, it offers a significant contribution to academic debates in international retailing. It is also refreshingly inclusive in extending the immediate theoretical domain of retailing into the broader domain of social science in search of new theories and ideas.

Reviewed by Latchezar Hristov, DPhil, Audencia Nantes School of Management, 8 Route de la Jonelière - B.P. 31222, 44312 Nantes Cedex 3, France. E-mail: lhristov@audencia.com

Note: If there are books you would like to see reviewed in this section, or you would like to submit a review, please contact the Book Review Editor, Jenny Buchan, $\mathrm{PhD}$, Taxation \& Business Law, Business School, University of New South Wales, Kensington, NSW 2052, Australia. E-mail: jm.buchan@unsw.edu.au 